\title{
Cross-talk between CD8+ T cells and natural killers: the role of mitochondrial Aa2+ transport
}

\author{
Roman Uzhachenko ${ }^{*}$, Shawn Goodwin ${ }^{1}$, Menaka Thounaojam, William Hofmeister ${ }^{2}$, Anil Shanker ${ }^{3}$ \\ From Society for Immunotherapy of Cancer 29th Annual Meeting \\ National Harbor, MD, USA. 6-9 November 2014
}

Unraveling complex interactions between immune cells is a key to the development of new strategies for immunotherapy. In the present study, we investigated functional outcome of bidirectional interaction between activated $\mathrm{CD} 8+\mathrm{T}$ and naive natural killer (NK) cells. We found that phorbol 12-myristate 13-acetate (PMA)/Ionomycin (Io)-stimulated CD8+T cells form multiple intercellular contacts with naive NK lymphocytes. Co-culture of activated $\mathrm{T}$ cells with naïve NK cells results in the selective down-regulation of CD25 molecule in T cells while elevating CD25 and CD69 expression on naive NK cells. Further, CD8+T and NK cells cross-regulate mitochondrial homeostasis including calcium transport. This effect is dependent on both cytokines and intercellular contacts, and partially involves natural killer group 2 member D (NKG2D) receptor activation. Data also suggest that activated CD8+T cells might directly transfer mitochondria and activation molecules such as CD25 and CD69 to naive NK cells. Alterations in phosporylation status of multiple signaling proteins during CD8 $+\mathrm{T} / \mathrm{NK}$ interaction suggest a functional remodeling whereby NK cells shift activated CD8+T cells towards $\mathrm{T}$ central-memory (TCM) phenotype and activated CD8 $+\mathrm{T}$ lymphocytes alter naive state of NK cells towards effector/regulatory phenotype. Inhibition of mitochondrial $\mathrm{Ca} 2+$ uptake $(\mathrm{mCU})$ or $\mathrm{Na}+/ \mathrm{Ca} 2+$ exchanger (mNCE) with Ru360 and CGP37157 respectively mimicked observed alterations in CD8+ and NK cells upon their interaction. These data suggest a potential role of mitochondrial $\mathrm{Ca} 2+$ homeostasis in the acquisition of mixed activation/regulatory phenotype by NK cells during $\mathrm{T}$ cell-NK cell interaction. We believe that understanding the mechanisms of CD8+-NK interplay will help to develop new approaches for cellular immunotherapy.

${ }^{1}$ Meharry Medical College, Nashville, TN, USA

Full list of author information is available at the end of the article
Authors' details

${ }^{1}$ Meharry Medical College, Nashville, TN, USA. ${ }^{2}$ University of TN Space Institute, Nashville, TN, USA. ${ }^{3}$ Meharry Medical College School of Medicine / Vanderbilt-Ingram Cancer Center, Nashville, TN, USA.

Published: 6 November 2014

doi:10.1186/2051-1426-2-S3-P189

Cite this article as: Uzhachenko et al:: Cross-talk between CD8+ T cells and natural killers: the role of mitochondrial Aa2+ transport. Journal for ImmunoTherapy of Cancer 2014 2(Suppl 3):P189.
Submit your next manuscript to BioMed Central and take full advantage of:

- Convenient online submission

- Thorough peer review

- No space constraints or color figure charges

- Immediate publication on acceptance

- Inclusion in PubMed, CAS, Scopus and Google Scholar

- Research which is freely available for redistribution 